\title{
EARLY GROWTH OF JABON (Anthocephalus cadamba Miq) IN A DRAINED PEATLAND OF PELALAWAN, RIAU
}

\author{
Ahmad Junaedi ${ }^{1 *}$, Nina Mindawati ${ }^{2}$, and Yanto Rochmayanto ${ }^{3}$ \\ ${ }^{1}$ Research Institute for Fiber Technology of Forest Plant Species; \\ Research, Development and Innovation Agency \\ Jl. Raya Bangkinang - Kuok, Kec. Kuok, Kab. Kampar, Prov. Riau, Indonesia \\ ${ }^{2}$ Forest Research and Development Center, Research, Development and Innovation Agency \\ Jl. Gunung Batu No.5, Bogor, West Java 16610, Indonesia \\ ${ }^{3}$ Center for Research and Development on Social, Economy, Policy and Climate Change, \\ Research, Development and Innovation Agency \\ Jl. Gunung Batu No.5, Bogor, West Java 16610, Indonesia
}

Received: 21 September 2020, Revised: 11 April 2021, Accepted: 12 April 2021

EARLY GROWTH OF JABON (Anthocephalus cadamba Miq.) IN A DRAINED PEATLAND OF PELALAWAN, RIAU. The desirability to explore other tree species that can be used to substitute Acacia crassicarpa in forest plantation has increased. One of the early insights that must be known is the growth performances of tree species candidates, especially in planting conditions (site and silviculture) similar to A. crassicarpa plantation. This study evaluated the growth performance of jabon (A. cadamba Miq.) and its relationship with soil properties in a drained peatland. The research was conducted by establishing experimental plots of jabon in a drained peatland (DP) using a randomised complete block design with three spacing $(2 \mathrm{~m} \times 3 \mathrm{~m}, 2.5 \mathrm{~m} \times 3 \mathrm{~m}, 3 \mathrm{~m} \times 3 \mathrm{~m})$ as treatment and three blocks as replications. The study observed survival, growth and soil chemical properties. At 24 months after planting (MaP), since the toxicity of soil micronutrients was excessive as one of the main factors; the mortality rate of jabon was high $(62 \%)$, while its growth was poor (height $=259 \mathrm{~cm}$ and $\mathrm{DBH}=3.74 \mathrm{~cm}$ ) in drained peatland. However, the study observed that $7 \%$ of jabon had good growth, with a range of height growth at $24 \mathrm{MaP}$ of 401-660 $\mathrm{cm}$. These results indicated that though overall jabon did not show good growth in DP, however, it was found that $7 \%$ of jabon had promising growth; therefore, it was suggested that through tree improvement program and certain treatments to overcome micronutrient toxicity and weed suppression, the possibility of jabon was able to be developed in a DP for forest plantation is still.

Keywords: Growth, Anthocephalus cadamba, Acacia crassicarpa, micronutrients toxicity, tree improvement

PERTUMBUHAN AWAL JABON (Anthocephalus cadamba Miq.) PADA LAHAN GAMBUT YANG DIDRAINASE DI PELALAWAN, RLAU. Dorongan untuk mencari jenis pohon sebagai pengganti A. crassicarpa di butan tanaman semakin meningkat. Salah satu informasi awal yang perlu diketabui adalab mengenai pertumbuban calon

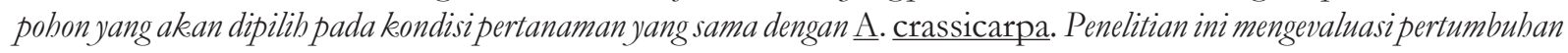
jabon (‥ cadamba) dan hubungannya dengan sifat tanah di lahan gambut yang didrainase. Penelitian dilakukan dengan membangun plot eksperimen penanaman jabon di lahan gambut yang didrainase, menggunakan rancangan acak. kelompok dengan tiga jarak tanam $(2 \times 2 m ; 2,5 m \times 3 m ; 3 m \times 3 m)$ sebagai perlakuan dan diulang sebanyak tiga bloke ulangan. Parameter yang diamati meliputi kemampuan bidup, pertumbuhan dan sifat kimia tanah. Sampai umur 24 bulan setelah tanam (BST), jabon menunjukkan tingkat kematian yang tinggi (62\%) dan rerata pertumbuban yang lambat (tinggi 259 $\mathrm{cm}$ dan diameter $3,74 \mathrm{~cm}$ ) di lahan gambut yang didrainase dikarenakan salah satunya oleh keracunan hara mikro berlebih. Meskipun demikian, sebanyak 7\% jabon mempunyai pertumbuban tinggi yang baik pada umur 24 BST, yakni berkisar 401-660 m. Hasil tersebut menunjuk.kan bahwa secara keseluruban jabon tidak menunjukkan pertumbuhan yang baik di laban gambut yang didrainase. Namun, adanya sebagian jabon (7\%) yang menunjukkan performa yang menjanjikan; maka melalui program pemuliaan pohon dan perlakuan silvikultur untuk mengatasi permasalahan keracunan bara mikro berlebih dan tekanan gulma, nampaknya jabon masib berpeluang untuk dikembangkan di lahan gambut yang didrainase. diharapkan jenis ini dapat dikembangkan melalui program pemuliaan pobon dan perlakuan silvikultur untuk. mengatasi permasalaban keracunan hara mikro berlebih dan tekanan gulma.

Kata kunci: Pertumbuhan, Anthocephalus cadamba, Acacia crassicarpa, keracunan hara mikro, pemuliaan pohon

*Corresponding author: ajunaedi81@yahoo.co.id 


\section{INTRODUCTION}

Indonesia is one of ten countries with the largest area of forest plantations in the world (Indufor, 2014, as cited by Barua, 2015). In total, the coverage area of forest plantations in Indonesia till 2019 reached around 5.1 million ha, and one of the most vital of that is pulpwood plantation/HTI-pulp (Ministry of Environment and Forestry, 2021). However, the productivity of HTI-pulp has decreased due to the low density of standing stock at harvest time. The survival rate of stand-in HTI-pulp at five years could reach less than 25\% (Junaedi, 2018b).

The decreasing HTI-pulp productivity existed in all land types, including in the peatland of Riau Province, expressed by the low productivity of Acacia crassicarpa (krassikarpa). The productivity of this species in second rotations was less than $140 \mathrm{~m}^{3} / \mathrm{ha}$ (Suhartati, Aprianis, Pribadi, \& Rahmayanto, 2013). Therefore, the decreasing HTI pulp productivity should be solved; due to Riau has a large area of HTI-pulp plantations (800 thousand ha), and more than 50\% was in peatland (Ministry of Environment and Forestry, 2016). One way to prevent a continual decline in HTI-pulp productivity is to explore alternative species that can grow well on peatland.

Jabon (Anthocephalus cadamba Miq.) was selected in this study as the tree species candidate that would be further evaluated for its probability to be grown in the peatland of HTI-pulp. Jabon is a pioneer species that can grow well in acidic soil and has been categorised as fast-growing species (Bijalwan, Dobriyal, \& Bhartiya, 2014b; Suhartati, Rahmayanti, \& Nurrohman, 2012). Furthermore, in a term as raw material for pulp and paper, fiberwood of jabon had good quality (Aprianis, 2016; Biswas, Misbahuddin, Roy, Francis, \& Bose, 2011).

In this study, the focus of the evaluation was on growth performances in the three planted spacing of the species in the conditions (site and silviculture) that were in general similar to krassikarpa plantation. A previous study of the growth of jabon in acidic ultisol soil showed that the growth performance of jabon was influenced by soil properties (Junaedi, 2018a); thus, the current study also investigated the role of soil properties on jabon growth. Therefore, the objectives of this study to evaluate the growth performance of jabon in peatland in general term and to evaluate growth performance of jabon in peatland as the effect of variation in planted spacing, and to investigate the relationship between the growth of jabon and soil properties in peatland. Furthermore, due to the standard of site management of peatland for HTI-pulp, the area has been drained; hence the scope of evaluation was for jabon, which was grown in drained peatland.

\section{MATERIAL AND METHOD}

\section{Site Description}

The study was conducted in a peatland that has been under forest concession of PT. Riau Andalan Pulp and Paper (RAPP). The location is at Pelalawan Sector, Compartment C-047 (based on estate administration, $00^{\circ} 32.071^{\prime} \mathrm{N}$ and $\left.102^{\circ} 05.469^{\prime} \mathrm{E}\right)$, Pelalawan District, Riau (Figure 1). The soil type of location is histosol with its dominant maturity of organic materials is fibric-hemic. Elevation of the location is at $8 \mathrm{~m}$. Elevation of the location is at $8 \mathrm{~m}$ a.s.l. The climate type of the location is A, with an average annual temperature, relative humidity and rainfall of $27^{\circ} \mathrm{C} ; 84 \% ; 2,100 \mathrm{~mm}$, respectively. The land was drained; the water table depth was kept more than $50 \mathrm{~cm}$ below the soil surface (Christianus, 2006). Previously, the land was used for the plantation forest of krassikarpa (second rotation).

\section{Plot Establishment}

The experimental plot was established based on the silviculture system commonly applied in RAPP for krassikarpa (Junaedi, 2018b). The targeted area was cleared using an excavator, and plots were established. There were three different spacing evaluated in this study, i.e. $2 \times 2 \mathrm{~m}, 2.5 \times 3 \mathrm{~m}$ and $3 \times 3 \mathrm{~m}$. The 


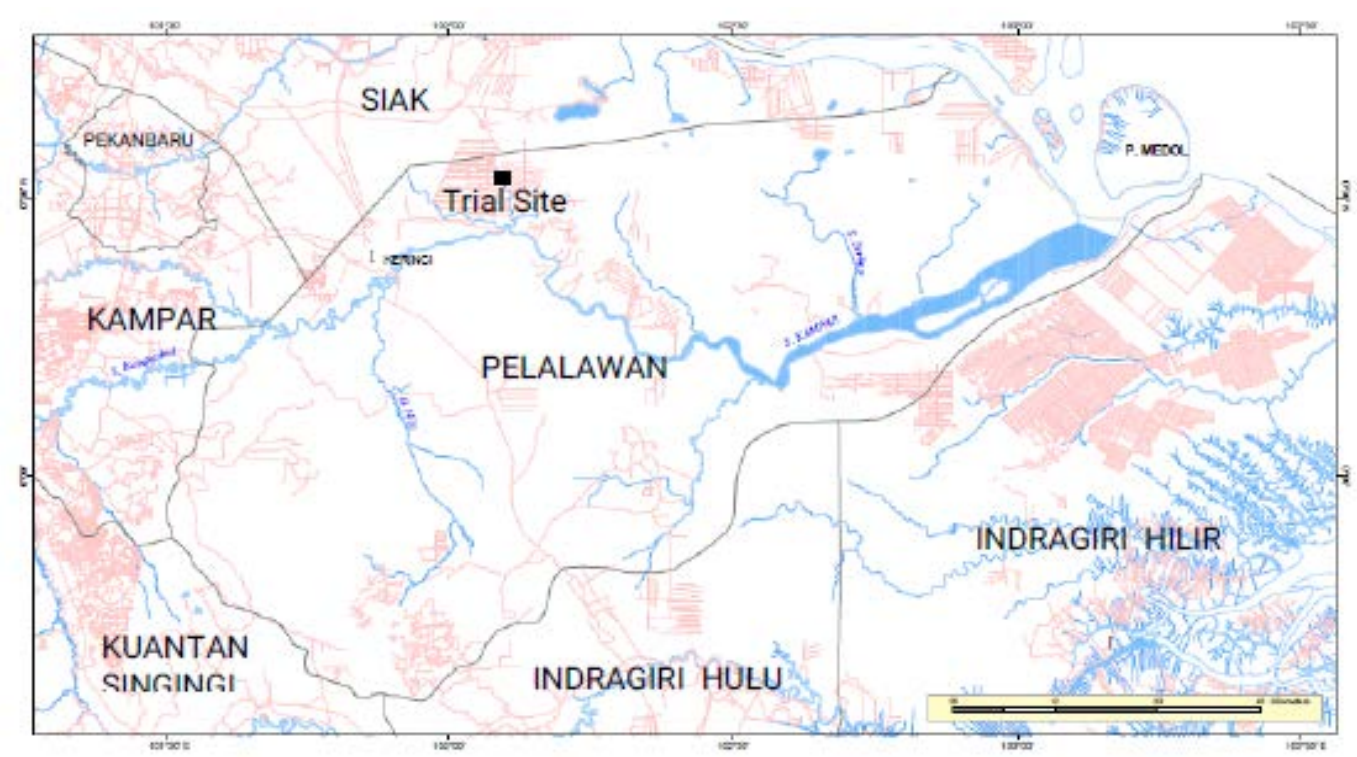

Figure 1. Location of the trial site in Pelalawan District, Riau

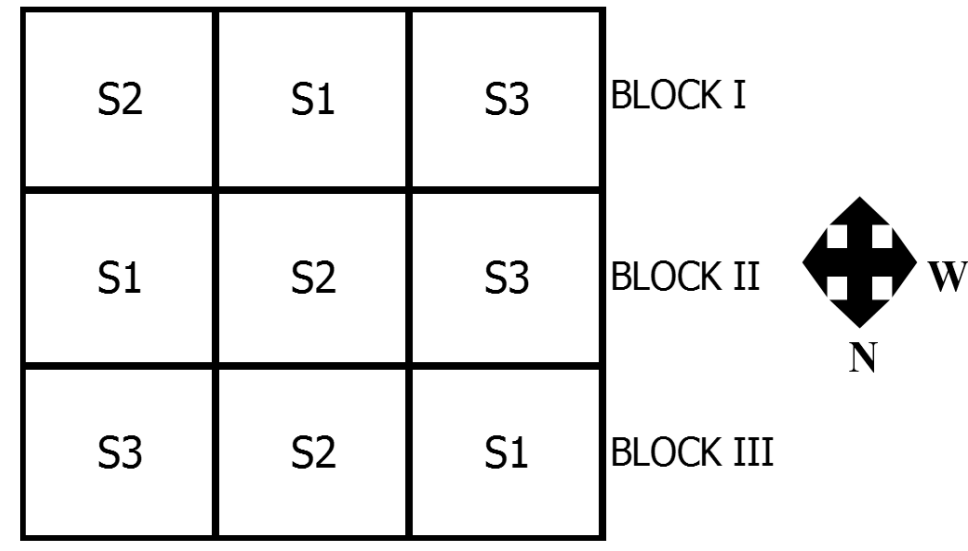

Figure 2. The design of experimental plots of jabon in a drained peatland of Pelalawan, Riau Remarks: $\mathrm{S} 1=2 \mathrm{~m} \times 2 \mathrm{~m}, \mathrm{~S} 2=2.5 \mathrm{~m} \times 3 \mathrm{~m}$ and $\mathrm{S} 3=3 \mathrm{~m} \times 3 \mathrm{~m}$

seedlings of jabon were planted according to a randomised complete block design (RCBD) with those spacing as single treatments and with three replications (Figure 2). The age of seedlings used for the plantation was about four months with the means of height and collar diameters of $18.5 \mathrm{~cm}$ and $4.38 \mathrm{~mm}$, respectively. The seedling originated from generative propagation, and the seed origin was identified by standing seed sources in Dramaga, Bogor, West Java (unimproved seed).

Similar fertilisation was applied when planting for all spacing treatment. The types and dosages per seedling were $250 \mathrm{~g}$ rock phosphate
$\left(\mathrm{Ca}_{3}\left(\mathrm{PO}_{4}\right)_{2} \mathrm{CaF}\right), 50 \mathrm{~g} \mathrm{KCl}, 10 \mathrm{~g}$ Ertibor $\left(\mathrm{Na}_{2}\right.$ $\left.\mathrm{B}_{4} \mathrm{O}_{7} \cdot 5 \mathrm{H}_{2} \mathrm{O}\right)$ and $10 \mathrm{~g}$ zincop $\left(\mathrm{ZnSO}_{4} \cdot \mathrm{H}_{2} \mathrm{O}\right.$ \& $\left.\mathrm{CuSO}_{4} \cdot 7 \mathrm{H}_{2} \mathrm{O}\right)$. A year after planting, jabon was intensively maintained through frequent weeding in three monthly intervals (manually with machete and hand removal) and one time pruning at six months after planting. Initially, based on the standard silviculture technique of krassikarpa, maintenance was not continued after one year. However, we found the weed was very dense in the plots when making the growth observation at the age of 18 months after planting (18 MaP); thus, a supplement weeding was done (once) after $18 \mathrm{MaP}$. 


\section{Field Measurements}

The survival rates and growth of jabon were measured at the ages of $3,6,12,18$, and 24 months after planting (MaP). The initial planning of observation was to continue till harvest time (i.e. five years). In terms of growth evaluation for pulpwood plantation, the study decided to not continue observation at the age after $24 \mathrm{MaP}$ ( 2 years). The survival rate was very low and tended to continue to decrease. In contrast, the growth rate tended to a standstill. The observation of all variables was undertaken based on spacing differences at 3, 6, and 12 $\mathrm{MaP}$. However, this spacing difference was not followed during the observation at $18 \mathrm{MaP}$ due to the high mortality of jabon in each spacing.

The number of live individuals was recorded during the time of observations. The survival rate then was quantified as the percentage/ proportion of individuals remaining after 3,6 , 12,18 , and 24 months since seedling planting. The observation of growth parameters was conducted on total height $(\mathrm{cm})$ and diameter breast height $(\mathrm{DBH}, \mathrm{cm})$. Total height was observed at all time of observations, while $\mathrm{DBH}$ was recorded at $18 \mathrm{MaP}$ and $24 \mathrm{MaP}$. Height was measured by measuring stick, while DBH by the calliper.

The soil properties were identified twice to examine the relationship between growth and soil properties. The first, soil sample was collected from five points (four points at each corners of plot and one point at the center; depth $=0-30 \mathrm{~cm}$ ) from the experiment plot and then combined to result in one composite sample. This work was done immediately after planting. Secondly, soil samples were collected at $7 \mathrm{MaP}$ on two different locations based on the growth data of $6 \mathrm{MaP}$. The locations were under stunted (jabon A) and good jabon (jabon B).

Soil samples were sent to the soil laboratory of the Forestry Research and Development Division, PT. RAPP in Pangkalan Kerinci, Riau for chemical analysis. Soil samples were analysed for content of total C (colourimetric method); total N (Kjeldahl method); the availability of $\mathrm{P}$ (bray II method), $\mathrm{K}, \mathrm{Ca}$ and $\mathrm{Mg}\left(\mathrm{NH}_{4} \mathrm{OAc}(\mathrm{pH}\right.$ 7.0, $1 \mathrm{~N}$ ) extraction method); total $\mathrm{B}, \mathrm{Cu}, \mathrm{Zn}$, $\mathrm{Fe}, \mathrm{Mn}(\mathrm{HCl} 25 \%$ extraction method) and total $\mathrm{Al}\left(\mathrm{HNO}_{3}+\mathrm{HClO}_{4}\right.$ extraction method) (Bray, \& Kurtz, 1945; Bremner \& Mulvaney, 1982; Eviati \& Sulaeman, 2009; Motsara \& Roy, 2008).

\section{Data Analysis}

One-Way ANOVA was performed to determine the effect of spacing on jabon growth at 3-12 $\mathrm{MaP}$ periods. However, ANOVA analysis was not run at 18 and 24 $\mathrm{MaP}$ to avoid bias. The possibility of bias was revealed due to high mortality caused by the massive change in current spacing compared to initial spacing treatments. Therefore, the data at 18 and $24 \mathrm{MaP}$ was analysed with descriptive analyses followed with descriptions in tabular and graphical forms.

\section{RESULTS AND DISCUSSION}

\section{A. The Survival Rate, Growth and Spacing Effect}

The survival rate of jabon at the age of 3-12 MaP period in drained peatland (DP) was not significantly different ( $p>0.05)$, based on spacing treatment. Furthermore, there was an abnormal result in the trend of survival rate at the age of 6-9 MaP period. The survival rate at $9 \mathrm{MaP}$ was higher than at $6 \mathrm{MaP}$ (Figure 3a). However, after $9 \mathrm{MaP}$, the survival declined till the last observation (24 MaP) and reached 38\%. This abnormal survival rate may be due to the number of trees that were observed as dead plants at the age of 3 and $6 \mathrm{MaP}$, categorised by physical symptoms such as wilting, defoliating and drying; however, several of them were regreening, and re-sprouting at $9 \mathrm{MaP}$; and thus were identified as live individuals.

Height of jabon was not significantly different $(p>0.05)$ between spacing treatments at the age of 3-12 MaP (Figure 3b). Furthermore, the increment of height and $\mathrm{DBH}$ showed relatively promising growth of jabon till 18 $\mathrm{MaP}$ (height increment $=170 \mathrm{~cm} /$ year and $\mathrm{DBH}$ increment $=1.72 \mathrm{~cm} /$ year). However, the height growth between 18-24 MaP was at 

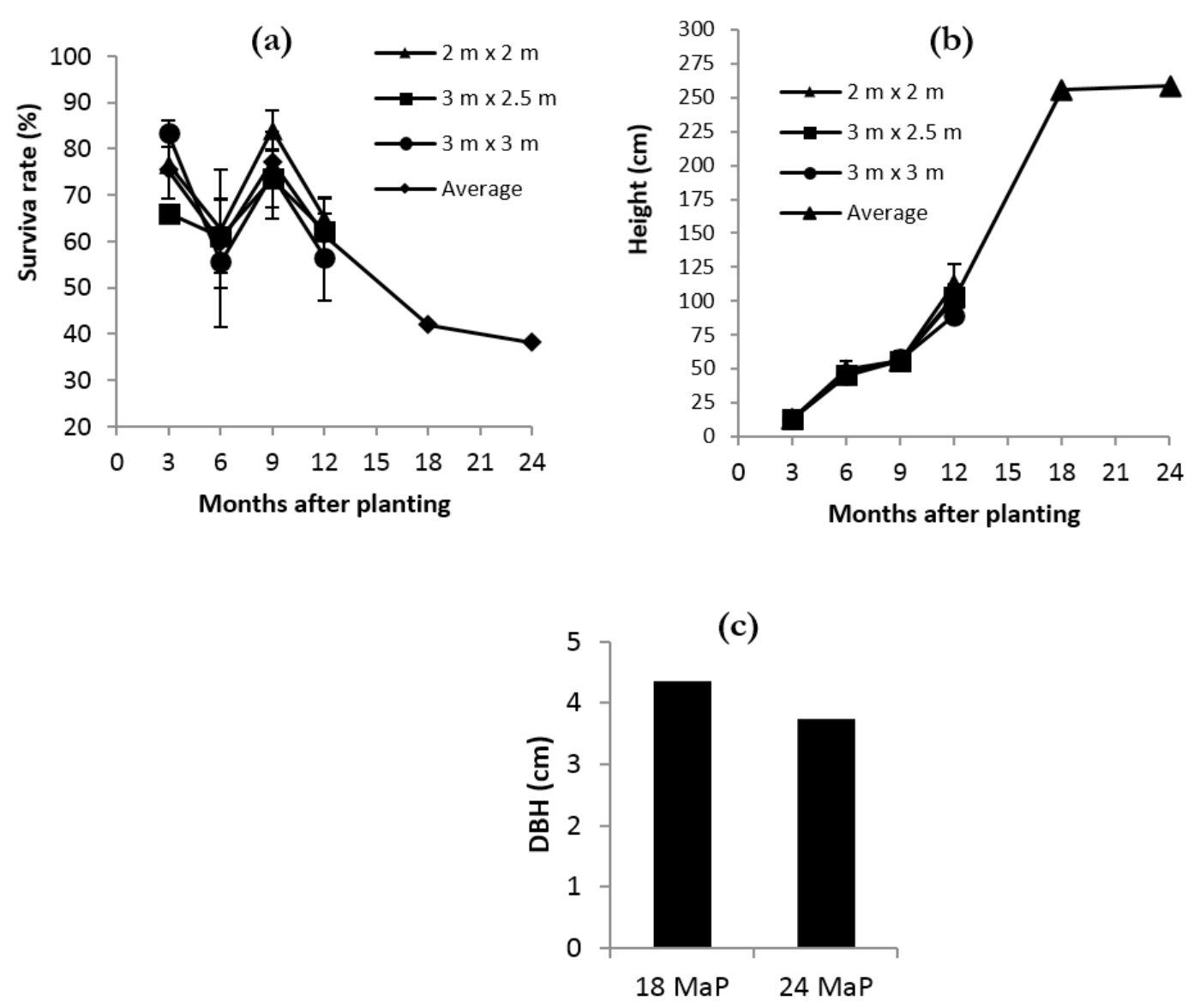

Figure 3. The survival rate (a), height growth (b) and diameter growth (c) of jabon in drained peatland

a standstill, even for the $\mathrm{DBH}$, and a negative growth increment was observed (Figure $3 \mathrm{c}$ ). At $24 \mathrm{MaP}$, the average height and $\mathrm{DBH}$ based on whole live individuals' data were $259 \mathrm{~cm}$ and $3.74 \mathrm{~cm}$. The stagnant or negative increment of growth of jabon in DP probably was because several jabon did not survive after reaching 24 MaP. Therefore, the average growth tended to a standstill for height and was negative for diameter.

Spacing treatment can influence plant competition in access to water, nutrient and sunlight (Ximenes, Mayun, \& Pradnyawathi, 2018; Yudianto, Fajriani, \& Aini, 2015). In this study, intraspecific competition within individual trees of jabon commenced from the first establishment till $12 \mathrm{MaP}$. The competition between jabon and other species (weed) could be neglected because the weed was regularly eradicated (three monthly). However, this intraspecific competition during the observation was not yet intensive. In this experiment, the intraspecific competition occurred at the time of early growth of jabon, when the resources (water and nutrient) requirement of the plant was relatively low. Moreover, the sunlight was unlimited for all individuals of jabon in the different spacing due to there was no canopy closure till $12 \mathrm{MaP}$. As a result, the spacing differences were not influenced yet on the difference of resources required by plants. Therefore, as previous results showed, the growth of jabon in DP during 3-12 MaP was not significantly different among spacing treatments. Similar results have been found in 2 years old Eucalyptus spin Brazil (Filho, Molayudego, \& González, 2018).

The classification of the height based on the collected data from all live individuals (without being distinguished by spacing differences) 
showed that most of jabon had slow growth at the age of 6,12, and $24 \mathrm{MaP}$ (Figure 4). For example, the proportion of height below 201 $\mathrm{cm}$ at the age of $24 \mathrm{MaP}$ was 21\% (Figure 4). However, a few jabon $(7 \%)$ showed promising growth until $24 \mathrm{MaP}$, and height growth could reach the range of 401-660 $\mathrm{cm}$ (Figure 4).

The high variation in growth between individuals of jabon may be because the seed source used in this experiment came from the identified seed source in Dramaga, Bogor, East Java. Seeds originated from an identified seed source class means that seeds are not yet superior. This is because the seed source has not yet been selected from a parent tree with good growth, nor was thinning done, resulting in bad quality trees. This causes a large variation in growth and survival rate when planted in other places. The progeny test of jabon also supported this suggestion in Java, Indonesia, which showed that the difference in height and diameter of jabon was greater among families than among provenances (Sudrajat, Nurhasybi, Siregar, Siregar, Mansur, \& Khumaida, 2016). Moreover, another factor that seems like the main factor in this growth variation in soil properties. However, specifically, the explanation of the effect of soil properties would be discussed further.

Overall, the results showed that jabon in DP had a low survival rate till $24 \mathrm{MaP}$ (2 years after planting). The survival rate was less than $60 \%$ (The Regulation of Forestry Ministry about a Manual for Evaluate the Successful of Forest Reclamation, 2009). Of course, this is an unexpected result, even though the observation was only made relatively young, not yet at harvest time. At a similar age, this survival rate was lower than that found in jabon in ultisol land $(84 \%)$ and also than that in krassikarpa (exotic species) with a survival rate of more than 80\% (Junaedi, 2018a; 2018b). Furthermore, for native tree species of tropical peat swamp forest (TPSF); the survival rate range of the pioneer (i.e. mahang (Macaranga pruinosa), geronggang (Cratoxylum arborescens), and skubung (Macaranga gigantea) and non-pioneer i.e. kelat (Eugenia sp.), kapurnaga (Calophyllum sp.), punak (Tetramerista glabra), and ramin (Gonystylus bancanus) species were $71-94 \%$ and 37-90\% (Daryono, 2009; Junaedi, 2018b).

Jabon growth also showed an unexpected result. Overall, in point of view, as fast-growing

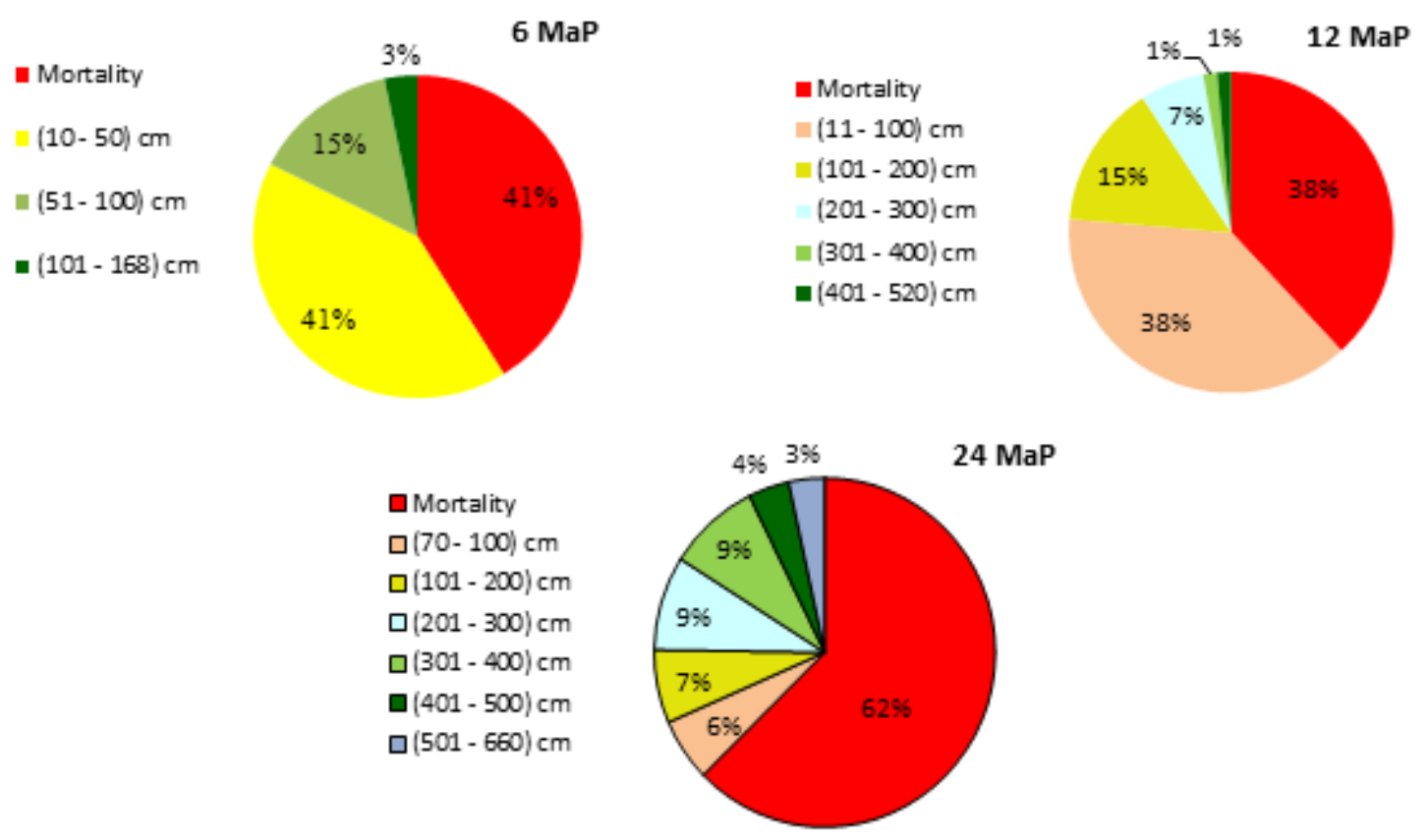

Figure 4. The distribution (\%) of jabon height in some classes at 6, 12 and $24 \mathrm{MaP}$ 
species, the growth of jabon in DP was poor. As fast-growing species, some previous studies showed that the height and DBH increments of jabon at 2-4 years in dryland could reach $1.62-4.21 \mathrm{~m} /$ year and $2.03-5.25 \mathrm{~cm} /$ year (Abdulah, Mindawati, Kosasih, \& Darwo, 2013; Bijalwan, Dobriyal, \& Bhartiya, 2014a; Seo, Chun, Mansur, \& Lee, 2015; Wahyudi, 2012; Zuhaidi, Hashim, Sarifah, \& Norhazaedawati, 2012; Zuhaidi, 2013). It means that the height and $\mathrm{DBH}$ of jabon in optimal growth in DP could reach $3.24-8.42 \mathrm{~m}$ and $4.06-10.50 \mathrm{~cm}$ at the age of $24 \mathrm{MaP}$, but in this study, it was 2.59 $\mathrm{m}$ and $3.74 \mathrm{~cm}$, respectively. The growth of jabon in DP was not better than that of jabon in marginal ultisol land with the average height and $\mathrm{DBH}$, at the age of $24 \mathrm{MaP}$, of more than $3 \mathrm{~m}$ and $3 \mathrm{~cm}$ (Junaedi, 2018a).

The toxicity of soil micronutrient was suggested as the main factor that made the poor growth of jabon in DP (this study) instead of in dryland as mentioned by Wahyudi (2012) in Central Kalimantan, Ahmad Zuhaidi (2013) in Sarawak-Malaysia, Seo, Kim, Chun, Mansur, and Lee (2015) in West Java and (Junaedi, 2018a) in Baserah-Riau. Possibly, it was caused by the fact that the content of soil micronutrient in dryland was less than that in DP. For instance, the exchangeable $\mathrm{Al}$ content in a ultisol soil at Baserah-Riau was less than 2.5 $\mathrm{cmol}(+) \mathrm{kg}^{-1}$ (Junaedi, 2018a), while in peat soil of Kalimantan was more than $3 \mathrm{cmol}(+) \mathrm{kg}^{-1}$
(Fahmi, Radjagukguk, Purwanto, \& Hanudin, 2012). Therefore, the toxicity rate in jabon, which was grown in dryland, was less than that in DP. Furthermore, this toxicity will be explained more in detail in the sub-discussion of Effect of Soil Properties on The Growth.

Furthermore, compared with native tree species of TPSF, the growth of jabon in DP was not better than pioneer species of TPSF such as mahang, skubung and geronggang. However, compared to the growth of nonpioneer species of TPSF Parashorea smythiessiz; the growth of jabon was better than the growth of slow-growing non-pioneer species such as kelat (Eugenia sp.) and ramin (Gonystylus bancanus) (Daryono, 2009; Hilwan, Setiadi, \& Rachman, 2013; Junaedi, 2018b; Lampela, Jauhiainen, Sarkkola, \& Vasander, 2017; Subiakto, Rachmat, $\&$ Sakai, 2016). The better performances of the pioneer native species might be related to their ability to overcome soil micronutrient toxicity through mechanisms. For instance, geronggang has a root system associated with arbuscular mycorrhiza (AM)(Tawaraya et al., 2003). AM in the root gives advantage to geronggang because it can reduce the detrimental effect of soil micronutrient toxicity (Rouphael, Cardarelli, \& Colla, 2015).

This study also suggested that one of the main causal factors of mortality and poor growth of jabon after $12 \mathrm{MaP}$ was weed suppression. The three monthly weedings
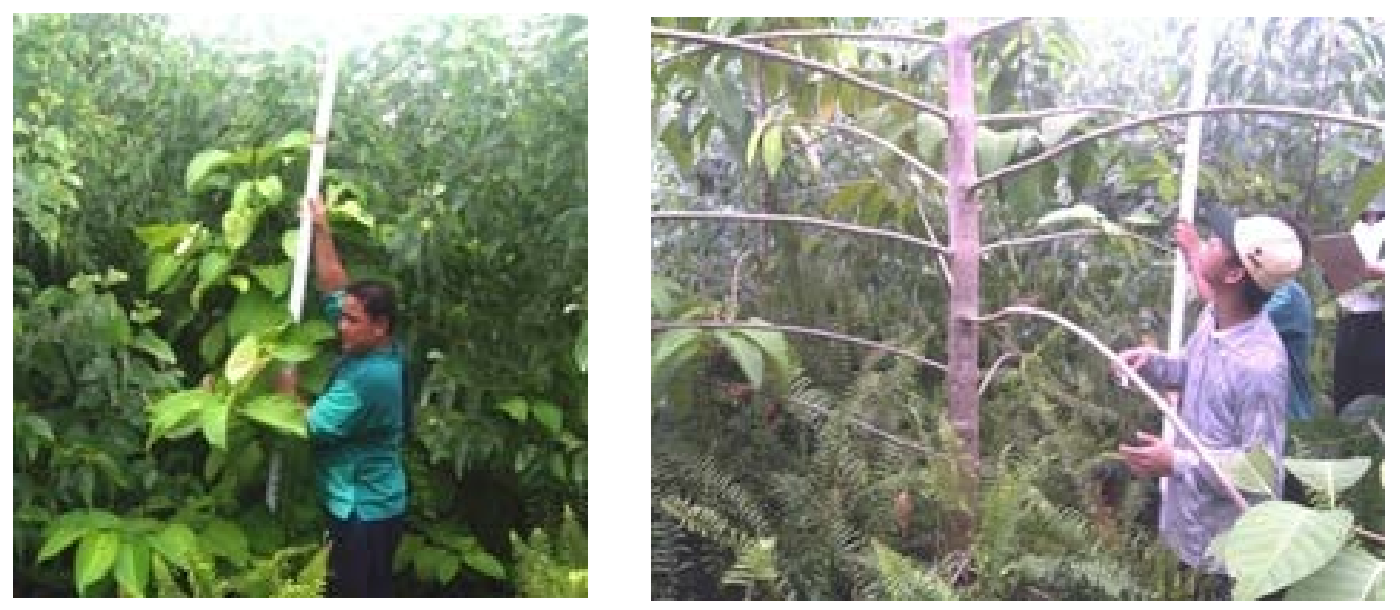

Figure 5. The high density (crowded) of weed around jabon stand at the age of $18 \mathrm{MaP}$ in drained peatland 
undertaken during the age of $0-12 \mathrm{MaP}$ were not continued further. Despite the impact, the study did not specifically observe some variables related to under-storey. Still, when the growth observation was made at $18 \mathrm{MaP}$, the study found dense weeds, particularly such as seedling-poles of krassikarpa and some tropical ferns (Figure 5). Moreover, the height of some of the krassikarpa pole was higher than jabon and shaded it. This evidence also showed that the supplement weeding done after $18 \mathrm{MaP}$ was too late and insufficient to save the survival and growth of jabon stand due to jabon is a pioneer species that need an open area to capture optimal sunlight their life and growth. This fact was also suggested to make the better survival rate and growth of jabon in a ultisol in Baserah, Riau, where the weed control was undertaken till 24 MaP (Junaedi, 2018a).

\section{B. Effect of Soil Properties on The Growth}

The chemical soil properties at the initial condition showed that the content of primary macronutrient $(\mathrm{N}, \mathrm{P}$ and $\mathrm{K})$ and micronutrient (Al, Fe and Mn) were high-very high (Tabel 1). Furthermore, the soil acidity was extremely acid. The high content of total $\mathrm{N}$ was the common condition in peat soil due to N's source from organic matter, which is relatively abundant. However, it was surprising that the content of $\mathrm{P}$ and $\mathrm{K}$ was also high. It was presumed that the high content of $\mathrm{P}$ and $\mathrm{K}$ had a relationship with the application of rock phosphate/RP $\left(\mathrm{Ca}_{3}\left(\mathrm{PO}_{4}\right)_{2} \mathrm{CaF}\right)$ and $\mathrm{KCl}$ fertilisers. Before establishing a jabon trial, $\mathrm{RP}$ as a $\mathrm{P}$ and $\mathrm{KCl}$ as a source of $\mathrm{K}$ were applied in previous silviculture practices to krassikarpa. As mentioned in the method, the trial's location previously was used for the plantation of krassikarpa. Furthermore, the high acidity and micronutrient of $\mathrm{Al}, \mathrm{Fe}$ and $\mathrm{Mn}$ content were common facts in drained peatland, as also were showed in some previous studies (Agus et al., 2020; Hikmatullah \& Sukarman, 2014; Husnain, Wigena, Dariah, Marwanto, Setyanto, \& Agus, 2014; Tuukkanen, Marttilla, \& Klove, 2017).

The high content of soil macronutrient in the plot was a good initial condition to support the growth of jabon. However, conversely, the existing high soil micronutrient of $\mathrm{Al}, \mathrm{Mn}$ and Fe made the soil extremely acid that was very harmful to the growth of jabon. In extremely acid soil, micronutrient solubility such as $\mathrm{Al}$ and $\mathrm{Fe}$ will increase and further toxic to the plant (Soewandita, 2018). Especially for Al, the potency of this element as a toxic element for the plant was shown in several cultivated peatlands in Central Kalimantan, South Kalimantan, Riau and Jambi (Hikmatullah \& Sukarman, 2014). Furthermore, based on soil sample analysis where the samples were collected from two locations in the experiment plot at $7 \mathrm{MaP}$, the soil properties tended to be different. The soil macronutrient under good jabon (jabon B) was higher than under stunted jabon (jabon A), but vice versa for micronutrients of $\mathrm{Fe}$ and $\mathrm{Mn}$ (Table 1).

$\mathrm{Al}$ in acidic soil $(\mathrm{pH}<5)$ demonstrated as the main toxic metal for plant (Hodson, 2012; Neenu \& Karthika, 2019; Rahman, Lee, Ji, Kabir, Jones, \& Lee, 2018). Based on the data of initial soil properties, the condition of the plots expressed an extremely acid state and had relatively high $\mathrm{Al}$, and this suggested that the Al toxicity was the main causal factor of the massive mortality and suppressed the growth of jabon, besides the use of unimproved seed and weed factors. Despite, it could not explain the detailed mechanism of the $\mathrm{Al}$ toxicity in jabon in the present study yet. The data associated with the physiology of the plant was not observed. However, some previous studies in other plants such as Vigna unguiculata, sugar maple and soybean showed that $\mathrm{Al}$ toxicity could inhibit nutrient uptake in the root system and also hindering root cell division and its elongation (Neenu \& Karthika, 2019; Schaberg, Tilley, Hawley, Dehayes, \& Bailey, 2006; Yu, Liu, Wang, Chen, \& Xu, 2011).

Based on this study, it is suggested that the role of soil micronutrient determine the growth difference between jabon A and jabon B. As reported before, the obtained micronutrient of Fe and Mn under jabon A was higher than that 
Table 1. Soil properties at initial condition, under stunted jabon (jabon A) and good jabon (jabon B)

\begin{tabular}{lcccc}
\hline Elements & Unit & Initial condition & Jabon A & Jabon B \\
\hline $\mathrm{pH} \mathrm{H}_{2} \mathrm{O}$ & - & $3.30 \pm 0.08^{\mathrm{EA}}$ & $3.217^{\mathrm{EA}}$ & $3.72^{\mathrm{EA}}$ \\
Macronutrients : & & & & \\
- C & $\%$ & $45.5 \pm 1.52^{\mathrm{VH}}$ & $40.17^{\mathrm{VH}}$ & $40.61^{\mathrm{VH}}$ \\
- Total N & $\%$ & $1.3 \pm 0.13^{\mathrm{VH}}$ & $1.46^{\mathrm{VH}}$ & $1,46^{\mathrm{VH}}$ \\
- Available P & $\mathrm{me} / 100 \mathrm{~g}$ & $39.55 \pm 4.49^{\mathrm{VH}}$ & $32.17^{\mathrm{VH}}$ & $39.11^{\mathrm{VH}}$ \\
- Available Ca & $\mathrm{me} / 100 \mathrm{~g}$ & $0.50 \pm 0.08^{\mathrm{VL}}$ & $1.06^{\mathrm{VL}}$ & $5.77^{\mathrm{L}}$ \\
- Available K & $\mathrm{me} / 100 \mathrm{~g}$ & $2.57 \pm 1.07^{\mathrm{VH}}$ & $0.22^{\mathrm{L}}$ & $0.46^{\mathrm{M}}$ \\
- Available Mg & $\mathrm{me} / 100 \mathrm{~g}$ & $2.27 \pm 0.17^{\mathrm{H}}$ & $0.59^{\mathrm{L}}$ & $1.10^{\mathrm{M}}$ \\
Micronutrients : & & & & \\
- Available Na & $\mathrm{me} / 100 \mathrm{~g}$ & $0.11 \pm 0.006^{\mathrm{L}}$ & $0.07^{\mathrm{VL}}$ & $0.10^{\mathrm{L}}$ \\
- Total B & $\mathrm{mg} / \mathrm{kg}$ & $3.65 \pm 0.84$ & 5.82 & 6.11 \\
- Total Cu & $\mathrm{mg} / \mathrm{kg}$ & $0.97 \pm 0.51^{\mathrm{S}}$ & $4.5^{\mathrm{S}}$ & $2.7^{\mathrm{S}}$ \\
- Total Fe & $\mathrm{mg} / \mathrm{kg}$ & $655.7 \pm 228.5^{\mathrm{VH}}$ & $995.60^{\mathrm{VH}}$ & $723.80^{\mathrm{VH}}$ \\
- Total $\mathrm{Mn}$ & $\mathrm{mg} / \mathrm{kg}$ & $10.16 \pm 3.163^{\mathrm{H}}$ & $77.05^{\mathrm{VH}}$ & $35.36^{\mathrm{VH}}$ \\
- Total $\mathrm{Zn}$ & $\mathrm{mg} / \mathrm{kg}$ & $3.31 \pm 0.54$ & 28.2 & 25.10 \\
- Total Al & $\mathrm{mg} / \mathrm{kg}$ & $1.6 \pm 94.03^{\mathrm{VH}}$ & & \\
\hline
\end{tabular}

Remarks : VL=very low, $\mathrm{L}=$ low, $\mathrm{M}=$ moderate, $\mathrm{H}=$ high, $\mathrm{VH}=$ very high, $\mathrm{EA}=$ extremely acid, $\mathrm{S}=$ sufficient $($ Eviati \& Sulaeman, 2009)

under jabon $\mathrm{B}$. The same as $\mathrm{Al}$, the excessive presence of $\mathrm{Fe}$ and $\mathrm{Mn}$ in the soil also would be toxic for the plant. Moreover, the excessive micronutrients such as $\mathrm{Al}, \mathrm{Mn}$ and $\mathrm{Fe}$ also negatively affected the growth of the plant through the antagonistic role on macronutrient uptake of $\mathrm{P}, \mathrm{K}, \mathrm{Ca}$ and $\mathrm{Mg}$ (Moosavi \& Ronaghi, 2011). The possibility that the toxicity rate and antagonistic role of those micronutrients in jabon $\mathrm{A}$ were higher than that in jabon $\mathrm{B}$, thus the growth of jabon $B$ was better than for jabon A. This concurred with several previous studies showing that some of the metal/micronutrients such as $\mathrm{Al}, \mathrm{Fe}$ and $\mathrm{Mn}$ were the limiting factors in the growth and productivity of some plant/ crop (Choudhury \& Sharma, 2014; Qadir, Schubert, \& Steffens, 2013; Rehmus, Bigalke, Valarezo, Mora, \& Wolfgang, 2014; Yu, Liu, Wang, Chen, \& Xu, 2011).

The degradation of photosynthetic pigments expressed the toxicity of Fe and Mn, the substantial damage in the components of root such as epidermal cells and membrane lipid and the biochemical disorder in cell $(\mathrm{Li}$ et al., 2012; Millaleo, Ivanov, Mora, \& Alberdi, 2010; Pereira et al., 2013; Yao et al., 2012; Youqiang, Hong, Dao-ming, \& Kun-zheng, 2012). As the impact, the plant's photosynthesis would be retarded and lead to the suppression of plant growth and death (Adamski, Peters, Danieloski, \& Bacarin, 2011; Nagajyoti, Lee, \& Sreekanth, 2010; Qadir, Schubert, \& Steffens, 2013). One of the symptoms of toxicity in the individual live plant was chlorosis (Kitao, Lei, Nakamura, \& Koike, 2001). The stunted jabon also showed this symptom in the present study (Figure 6a).

The difference of macronutrients (except N) under two contrasting jabon also suggested that it had a role in the difference of jabon growth. The soil under jabon B had less toxic micronutrient; it had more macronutrient than that under jabon A. This means that the supply of macronutrient required for plant growth was relatively more sufficient in the soil under jabon 


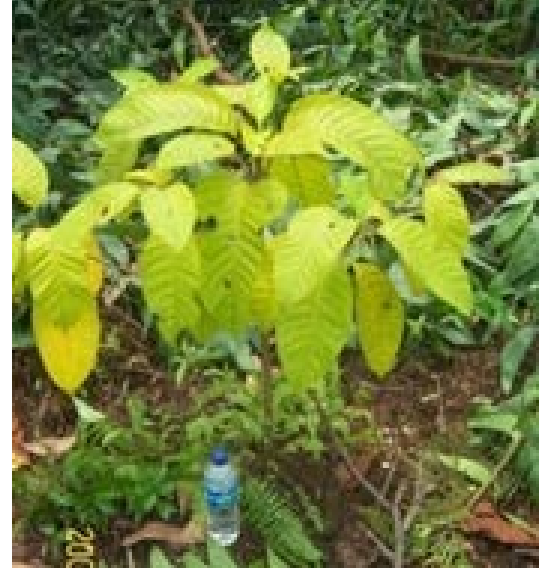

(a)

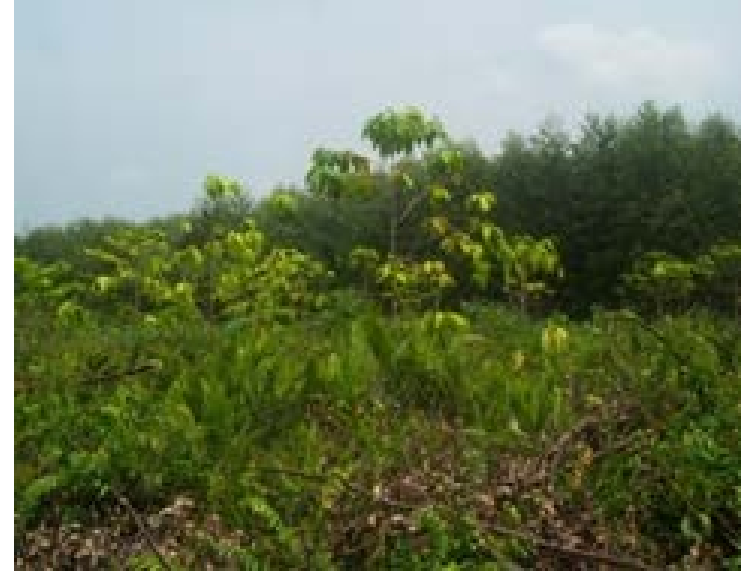

(b)

Figure 6. Chlorosis symptoms on stunned (a) and good (b) jabon in drained peatland

B than jabon A. Results showed that the less the micronutrient and the more the macronutrient was in drained peatland that had a positive effect on jabon growth. However, it was suggested that this positive effect could not be sustained because the growth in all live individuals was stagnant after $18 \mathrm{MaP}$, including in jabon that had relatively good growth in the period from 6 to $12 \mathrm{MaP}$. Moreover, several of the good jabon has died at $24 \mathrm{MaP}$, and some of the remaining live individuals showed chlorosis symptoms (Figure 6b).

\section{Implication}

Our research has not yet proven that jabon was suitable to be grown in DP in pulpwood plantation. The research also could not evaluate the species till harvest time that commonly is used in pulpwood plantation (about five years) due to the very high mortality of jabon. However, the research obtained some relatively valuable findings from the relatively short term (till two years). It must be noticed for the development of the species as one of the candidates to be grown in DP for pulpwood plantation. The use of unimproved seedling was one factor that made unexpected growth of jabon in DP. Nevertheless, from this unimproved seedling, the research obtained $7 \%$ jabon, which had promising growth at $24 \mathrm{MaP}$, heightened by more than $400 \mathrm{~cm}$ (Increment of height $>2 \mathrm{~m} /$ year). The growth trait in $7 \%$ of jabon could be interpreted as the signal that the opportunity to obtain improved seed/seedling that will result in better growth of jabon in DP is good.

The serious weed-suppressing survival and growth in the period of 1-2 years indicated that weed control (weeding) is still needed at least two years for jabon plantation in DP. This weeding control (till two years) in rubber tree and Eucalyptus hybrid has a positive effect on the growth, thus being used in jabon plantation (Guzzo, De Carvalho, Giancotti Alves, Gonçalves, \& Martins, 2014; Wirabuana, Sadono, Juniarso, \& Idris, 2020). The negative effect or toxicity of the excessive $\mathrm{Al}, \mathrm{Fe}$ and $\mathrm{Mn}$ on survival and growth rates of jabon in DP indicated that certain treatments are needed to overcome this serious problem. Some previous studies on other species showed that this toxicity could be hindered or at least alleviated through the application of soil ameliorants such as lime $\left(\mathrm{CaCO}_{3}\right)$, silicon ( $\left.\mathrm{Si}\right)$ and compost (Chatzistathis, Alifragis, \& Papaioannou, 2015; Karak, Sonar, Paul, Frankowski, Boruah, Dutta, \& Das, 2015; Prabagar, Hodson, \& Evans, 2011; Wu, Shi, Zhu, Wang, \& Gong, 2013; You-qiang, Hong, Dao-ming, \& Kun-zheng, 2012). Moreover, the application of arbuscular mycorrhizal inoculation around the root system was another treatment that could be chosen 
to overcome this toxicity problem (Rouphael, Cardarelli, \& Colla, 2015; Turjaman et al., 2011). In practice, tree improvement is required to determine the best seed of jabon with good growth and tolerance to the DP area. It is also important to examine which individuals of jabon are resistant to toxic micronutrients.

\section{CONCLUSION}

Our study was the first research that evaluated the growth performances of jabon in drained peatland for pulpwood plantation. This study provided the data of survival and growth rate of jabon in drained peatland and provided the soil properties data under jabon stand and its relationship with growth performance. These data were valuable for tree selection as the candidate for pulpwood plantation in drained peatland (DP). It showed that generally, jabon had a poor survival rate and growth in DP due to the use of unimproved seedling, the weed suppression at the age after $12 \mathrm{MaP}$ and the metal/micronutrient toxicity Al, Fe and Mn. However, the study obtained that $7 \%$ of jabon in DP had promising growth at $24 \mathrm{MaP}$ (height increment $>2 \mathrm{~m} /$ year); thus, this fact is valuable to be followed up by a tree improvement program.

\section{ACKNOWLEDGEMENT}

The authors are very grateful to the Research Institute for Fiber Forest, The Ministry of Environment and Forestry of Indonesia to support our research and provide the funding. Authors are also grateful to Tateng Sasmita, Syasri Janneta, Sunarto, Arifin, Ramiduk and Minal Aminin for field assistances and Dodi Frianto for sharing valuable references and Pak Saeful Iksan for providing the map of the study site. We would also like to thank the Research and Development Division of PT. RAPP for all valuable support, assistance, accommodation in the field and the laboratory.

\section{REFERENCES}

Abdulah, L., Mindawati, N., Kosasih, A. S., \& Darwo. (2013). Early growth evaluation of Neolamarckia cadamba Roxb at private forest. Jurnal Penelitian Hutan Tanaman, 10(3), 119128. doi://10.20886/jpht.2013.10.3.119-127.

Adamski, J. M., Peters, J. A., Danieloski, R., \& Bacarin, M. A. (2011). Excess iron-induced changes in the photosynthetic characteristics of sweet potato. Journal of Plant Physiology, 168(17), 2056-2062. doi://10.1016/j. jplph.2011.06.003.

Agus, C., Ilfana, Z. R., Azmi, F. F., Rachmanadi, D., Widiyatno, Wulandari, D., ...Lestari, T. (2020). The effect of tropical peat land-use changes on plant diversity and soil properties. International Journal of Environmental Science and Technology, 17(3), 1703-1712. doi://10.1007/ s13762-019-02579-x.

Aprianis, Y. (2016). The possibillity of alternative wood for pulp. In A. Hidayat, Sudarmalik, E. Novriyanti, H. H. Rachmat, \& A. Wahyudi (Eds.), The Proceeding of Research Finding: Opputunities and Challanges of The Development of Environment and Forestry in Riau (pp. 1-11). Balai Litbang Teknologi Serat Tanaman Hutan.

Barua, S. K. (2015). Plantation vision: Potentials, challenges and policy options for global industrial forest plantation development. International Forestry Review, 16(2), 117-127 doi://10.1505/146554814811724801.

Bijalwan, A., Dobriyal, M. J., \& Bhartiya, J. K. (2014a). A potential fast growing tree for agroforestry and carbon sequestration in a potential fast growing tree for agroforestry and carbon sequestration in India: Anthocephalus cadamba (Roxb.). American Journal of Agriculture and Forestry, 2(6), 296-301. doi://10.11648/j. ajaf.20140206.21.

Bijalwan, A., Dobriyal, M. J. R., \& Bhartiya, J. K. (2014b). A potential fast growing tree for Agroforestry and carbon sequestration in India: Anthocephalus cadamba (Roxb.). American Journal of Agriculture and Forestry, 2(6), 296301. doi://10.11648/j.ajaf.20140206.21.

Biswas, D., Misbahuddin, M., Roy, U., Francis, R. C., \& Bose, S. K. (2011). Bioresource technology effect of additives on fiber yield improvement for kraft pulping of kadam (Anthocephalus 
chinensis). Bioresource Technology, 102, 1284 1288. doi://10.1016/j.biortech.2010.08.059.

Bray, R.H. \& Kurtz, L. T. (1945). Determination of total, organic and available forms of phosphorus in soils. Soil Sciences, 59, 39-45.

Bremner, J. M., \& Mulvaney, C. S. (1982). NitrogenTotal, Part 2. In A. L. Page, R. H. Miller, \& D. R. Keeney (Eds.), Method of Soil Analysis Part 2 (2 $2^{\text {nd }}$ ed., p. 595-624). American Society of Agronomy, Inc. \& Soil Science Society of America, Inc.

Chatzistathis, T., Alifragis, D., \& Papaioannou, A. (2015). The influence of liming on soil chemical properties and on the alleviation of manganese and copper toxicity in Juglans regia, Robinia psendoacacia, Eucalyptus sp. and Populus sp. plantations. Journal of Environmental Management, 150, 149-156. doi://10.1016/j. jenvman.2014.11.020.

Choudhury, S., \& Sharma, P. (2014). Plant physiology and biochemistry aluminum stress inhibits root growth and alters physiological and metabolic responses in chickpea (Cicer arietinum L.). Plant Physiology and Biochemistry, 85, 63-70. doi://10.1016/j.plaphy.2014.10.012.

Christianus, S. (2006). The experience of the establishment of industrial plantation forest in PT. RAPP, Pelalawan-Riau (pp. 87-100). Wetlands International.

Daryono, H. (2009). Potency, problems, policy and peatland management needed for sustainable peat swamp forest. Jurnal Analisis Kebijakan Kebutanan, 6(2), 71-101.

Eviati, \& Sulaeman. (2009). Manual for chemical analysis of soil, plant and fertilise. B. H. Prasetyo, D. Santoso, \& L. Retno W (Eds.); $2^{\text {nd }}$ ed.). Research Institute for Soil.

Fahmi, A., Radjagukguk, B., Purwanto, B. H., \& Hanudin, E. (2012). The influnece of peatlayer on hydrogen and aluminium concentration originating from the substratum sulphidic materials. Journal of Tropical Soils, 17(3), 197202. doi://10.5400/jts.2012.17.3.197.

Filho, A. C. F., Mola-yudego, B., \& González-, J. R. (2018). Thinning regimes and initial spacing for Eucalyptus plantations in Brazil. Annals of the Brazilian Academy of Sciences, 90(1), 255265.

Guzzo, C. D., De Carvalho, L. B., Giancotti, P. R. F., Alves, P. L. C., Gonçalves, E. C. P., \& Martins, J. V. F. (2014). Impact of the timing and duration of weed control on the establishment of a rubber tree plantation. Anais $D a$ Academia Brasileira de Ciencias, 86(1), 495-504. doi://10.1590/0001-37652014119113.

Hikmatullah, \& Sukarman. (2014). Physical and chemical properties of cultivated peat soils in four trial sites of ICCTF in Kalimantan and Sumatra, Indonesia. Journal of Tropical Soils, 19(3), 131-141. doi://10.5400/ jts.2014.19.3.131.

Hilwan, I., Setiadi, Y., \& Rachman, H. (2013). Evaluation of some Dipterocarp species in revegetation areas of PT. Kitadin, East Kalimantan. Jurnal Silvikultur Tropika, 04(02), 108-112.

Hodson, M. J. (2012). Metal toxicity and tolerance in plants. Features, 28 October. doi://10.1042/ BIO03405028.

Husnain, H., Wigena, I. G. P., Dariah, A., Marwanto, S., Setyanto, P., \& Agus, F. (2014). $\mathrm{CO}_{2}$ emissions from tropical drained peat in Sumatra, Indonesia. Mitigation and Adaptation Strategies for Global Change, 19(6), 845-862. doi://10.1007/s11027-014-9550-y.

Junaedi, A. (2018a). Growth of Anthocephalus cadamba Miq. in marginal land ultisol in Riau. Jurnal Pemuliaan Tanaman Hutan, 12(1), 51-63. doi://10.20886/jpth.2018.12.1.51-63.

Junaedi, A. (2018b). Growth performance of three native tree species for pulpwood plantation in drained peatland of Pelalawan District, Riau. Indonesian Journal of Forestry Research, 5(2), 119132. doi//10.20886/ijfr.2018.5.2.119-132.

Karak, T., Sonar, I., Paul, R. K., Frankowski, M., Boruah, R. K., Dutta, A. K., \& Das, D. K. (2015). Aluminium dynamics from soil to tea plant (Camellia sinensis L.): Is it enhanced by municipal solid waste compost application? Chemosphere, 119, 917-926. doi://10.1016/j. chemosphere.2014.08.067.

Kitao, M., Lei, T. T., Nakamura, T., \& Koike, T. (2001). Manganese toxicity as indicated by visible foliar symptoms of Japanese white birch (Betula platyphylla var. japonica). Environmental Pollution, 111, 89-94.

Lampela, M., Jauhiainen, J., Sarkkola, S., \& Vasander, H. (2017). Promising native tree species for reforestation of degraded tropical peatlands. Forest Ecology and Management, 394, 52-63. doi://10.1016/j.foreco.2016.12.004.

Li, X., Ma, H., Jia, P., Wang, J., Jia, L., Zhang, T., Yang, 
Y., Chen, H., \& Wei, X. (2012). Responses of seedling growth and antioxidant activity to excess iron and copper in Triticum aestivum $\mathrm{L}$. Ecotoxicology and Environmental Safety, 86, 4753. doi://10.1016/j.ecoenv.2012.09.010.

Millaleo, R., Ivanov, A. G., Mora, M. L., \& Alberdi, M. (2010). Manganese as essential and toxic element for plants: transport, accumulation and resistance mechanisms. Journal Soil Science Plant Nuts., 10(4), 476-494.

Ministry of Enviroment and Forestry. (2021). The statistic of Ministry of Enviroment and Forestry 2019. The Ministry of Environment and Forestry, Jakarta.

The Regulation of Forestry Ministry about a Manual for evaluate the succesfull of forest reclamation (2009). The Ministry of Forestry, Jakarta.

Ministry of Environment and Forestry. (2016). The statistic of Environment and Forestry 2015. The Ministry of Environment and Forestry, Jakarta.

Moosavi, A. A., \& Ronaghi, A. (2011). Influence of foliar and soil applications of iron and manganese on soybean dry matter yieldand iron-manganese relationship in a Calcareous soil and iron-manganese relationship in a Calcareous soil. Australian Journal of Crop Science, 5(12), 1550-1556.

Motsara, M. R., \& Roy, R. N. (2008). Guide to laboratory establishment for plant nutrient analysis. FAO.

Nagajyoti, P. C., Lee, K. D., \& Sreekanth, T. V. M. (2010). Heavy metals, occurrence and toxicity for plants : a review. Environmental Chemistry Lett, 8, 199-216. doi://10.1007/s10311-0100297-8.

Neenu, S., \& Karthika, K. S. (2019). Aluminium toxicity in soil and plants. Harit Dhara, 2(1), 15-19.

Pereira, E. G., Oliva, M. A., Gusmão, E., Antonio, M., Rosado-souza, L., Camargo, G., Santos, D., Henrique, C., \& Miyasaka, A. (2013). Iron excess affects rice photosynthesis through stomatal and non-stomatal limitations. Plant Science, 201-202(March), 81-92. doi://10.1016/j.plantsci.2012.12.003.

Prabagar, S., Hodson, M. J., \& Evans, D. E. (2011). Silicon amelioration of aluminium toxicity and cell death in suspension cultures of Norway spruce (Picea abies (L.) Karst.).
Environmental and Experimental Botany, 70, 266276. doi://10.1016/j.envexpbot.2010.10.001. Qadir, M., Schubert, S., \& Steffens, D. (2013). Phytotoxic substances in soils. Reference Module in Earth Systems and Environmental Sciences, April, 1-6.doi://10.1016/B978-0-12-4095489.05255-6.

Rahman, A., Lee, S., Ji, H. C., Kabir, A. H., Jones, C. S., \& Lee, K. (2018). Importance of mineral nutrition for mitigating aluminum toxicity in plants on acidic soils : Current status and opportunities. International Journal of Molecular Sciences, 19(3073), 1-28. doi: //10.3390/ ijms19103073.

Rehmus, A., Bigalke, M., Valarezo, C., Mora, J., \& Wolfgang, C. (2014). Aluminum toxicity to tropical montane forest tree seedlings in southern Ecuador: response of biomass and plant morphology to elevated $\mathrm{Al}$ concentrations. Plant Soil, 382, 301-315. doi://10.1007/s11104-014-2110-0.

Rouphael, Y., Cardarelli, M., \& Colla, G. (2015). Role of arbuscular mycorrhizal fungi in alleviating the adverse effects of acidity and aluminium toxicity in zucchini squash. Scientia Horticulturae, 188, 97-105. doi://10.1016/j. scienta.2015.03.031.

Schaberg, P. G., Tilley, J. W., Hawley, G. J., Dehayes, D. H., \& Bailey, S. W. (2006). Associations of calcium and aluminum with the growth and health of sugar maple trees in Vermont. Forest Ecology and Management, 223, 159-169. doi://10.1016/j.foreco.2005.10.067.

Seo, J., Kim, H., Chun, J.-H., Mansur, I., \& Lee, C.B. (2015). Silvicultural practice and growth of the jabon tree (Anthocephalus cadamba Miq.) in community forests of West Java, Indonesia. Journal of Agriculture \& Life Science, 49(4), 8193.

Soewandita,H. (2018). A study of water management and palm oil productivity in peatlands (Case study: Peatlands of PT Jalin Vaneo's palm plantation in North Kayong District, West Kalimantan Province). Jurnal Sains \& Teknologi Modifikasi Cuaca, 19(1), 41-50.

Subiakto, A., Rachmat, H. H., \& Sakai, C. (2016). Choosing native tree species for establishing man-made forest: A new perspective for sustainable forest management in changing world. Biodiversitas, 17(2), 620-625. doi://doi. org/10.13057/biodiv/d170233. 
Sudrajat, D. J., Nurhasybi, Siregar, I. Z., Siregar, U. J., Mansur, I., \& Khumaida, N. (2016). Intraspecific variation on early growth of Neolamarckia cadamba Miq. in provenanceprogeny tests in West Java Province, Indonesia. Biotropia, 23(1), 10-20. doi: //10.11598/ btb.2016.2.

Suhartati, Rahmayanti, S., \& Nurrohman, E. (2012). Sebaran dan persyaratan tumbuh jenis alternatif penghasil pulp di wilayah Riau. In N. Mindawati, P. Pamoengkas, \& U. Sutisna (Eds.). Kementerian Kehutanan.

Suhartati, S., Aprianis, Y., Pribadi, A., \& Rochmayanto, Y. (2013). Study of reduction cycle impact of Acacia crassicarpa A. Cunn plantation to production value and social aspect. Jurnal Penelitian Hutan Tanaman, 10(2), 109-117. doi://10.20886/jpht.2013.10.2.109117.

Tawaraya, K., Takaya, Y., Turjaman, M., Tuah, S. J., Limin, S. H., Tamai, Y., Cha, J. Y., Wagatsuma, T., \& Osaki, M. (2003). Arbuscular mycorrhizal colonisation of tree species grown in peat swamp forests of Central Kalimantan, Indonesia. Forest Ecology and Management, 182(1-3), 381-386. doi://10.1016/S03781127(03)00086-0.

Turjaman, M., Santoso, E., Susanto, A., Gaman, S., Limin, S. H., Tamai, Y., Osaki, M., \& Tawaraya, K. (2011). Ectomycorrhizal fungi promote growth of Shorea balangeran in degraded peat swamp forests. Wetlands Ecology and Management, 19(4), 331-339. doi://10.1007/ s11273-011-9219-1.

Tuukkanen, T., Marttilla, H., \& Klove, B. (2017). Predicting organic matter, nitrogen, and phosphorus concentrations in runoff from peat extraction sites using partial least squares regression. Water Resources Research, 53, 58605876. doi://10.1002/2017WR020557.

Wahyudi. (2012). Growth and yield analysis of jabon plantation (Anthocephallus cadamba). Jurnal Perennial, 8(1), 19-24.

Wirabuana, P. Y. A. P., Sadono, R., Juniarso, S., \& Idris, F. (2020). Interaction of fertilisation and weed control influences on growth, biomass, and carbon in eucalyptus hybrid ( $E$. pellita $\times$ E. brassiana). Jurnal Manajemen Hutan Tropika, 26(2), 144-154. doi://10.7226/ JTFM.26.2.144.
Wu, J. W., Shi, Y., Zhu, Y. X., Wang, Y. C., \& Gong, H. J. (2013). Mechanisms of enhanced heavy metal tolerance in plants by silicon: A review. Pedosphere, 23(6), 815-825. doi: //10.1016/ S1002-0160(13)60073-9.

Ximenes, M. P., Mayun, I. A., \& Pradnyawathi, N. L. M. (2018). The combined effect of plant spacing and varieties on the growth and the corn yields (Zea mays L.) at Loes, Sub District of Maubara, District of Liquisa Repupublica Democratica De Timor Leste Plant. E-jurnal Agroteknologi Tropika, 7(2), 295-303.

Yao, A. Y., Donglin, M., Gang, X., Lutts, S., Achal, V., \& Ma, J. (2012). Contrasting performance and different tolerance of chestnut rose and grape to excess manganese. Journal Plant Growth Regulator, 31, 416-426. doi://10.1007/ s00344-011-9251-7.

You-qiang, F. U., Hong, S., Dao-ming, W. U., \& Kun-zheng, C. A. I. (2012). Silicon-mediated amelioration of $\mathrm{Fe} 2+$ toxicity in rice (Oryza sativa L.) roots. Pedosphere, 22(6), 795-802. doi://10.1016/S1002-0160(12)60065-4.

Yu, H. N., Liu, P., Wang, Z. Y., Chen, W. R., \& Xu, G. D. (2011). The effect of aluminum treatments on the root growth and cell ultrastructure of two soybean genotypes. Crop Protection, 30(3), 323-328. doi://10.1016/j. cropro.2010.11.024.

Yudianto, A. Y., Fajriani, S., \& Aini, N. (2015). Influence of plant spacing and pilled frequency on growth and yield of arrowroot plant (Marantha arundinaceae L.). Jurnal Produksi Tanaman, 3(3), 172-181.

Zuhaidi, Y.A., Hashim, M. N., Sarifah, K., \& Norhazaedawati, B. (2012). Domestication of lesser known tropical species Neolamarckia cadamba among the small scale forest owners. FRIM, Malaysia.

Zuhaidi, Y Ahmad. (2013). Crown diameter prediction model for plantation-grown Neolamarckia cadamba. Journal of Tropical Forest Science, 25(4), 446-453. 